\title{
Identification of Differentially Expressed Kinase and Screening Potential Anticancer Drugs in Papillary Thyroid Carcinoma
}

\author{
Huairong Zhang, ${ }^{1}$ Bo Gao, ${ }^{2}$ and Bingyin Shi ${ }^{1}$ \\ ${ }^{1}$ Department of Endocrinology, First Affiliated Hospital of Xian Jiaotong University, Xian, Shaanxi 710061, China \\ ${ }^{2}$ Department of General Surgery, First Affiliated Hospital of Harbin Medical University, Harbin, Heilongjiang 15001, China \\ Correspondence should be addressed to Bo Gao; bo.gaomichael@gmail.com and Bingyin Shi; zhrzhr0814@163.com
}

Received 30 May 2016; Accepted 8 August 2016

Academic Editor: Stamatios Theocharis

Copyright (c) 2016 Huairong Zhang et al. This is an open access article distributed under the Creative Commons Attribution License, which permits unrestricted use, distribution, and reproduction in any medium, provided the original work is properly cited.

\begin{abstract}
Aim. We aim to identify protein kinases involved in the pathophysiology of papillary thyroid carcinoma (PTC) in order to provide potential therapeutic targets for kinase inhibitors and unfold possible molecular mechanisms. Materials and Methods. The gene expression profile of GSE27155 was analyzed to identify differentially expressed genes and mapped onto human protein kinases database. Correlation of kinases with PTC was addressed by systematic literature search, GO and KEGG pathway analysis. Results. The functional enrichment analysis indicated that "mitogen-activated protein kinases pathway" expression was extremely enriched, followed by "neurotrophin signaling pathway," "focal adhesion," and "GnRH signaling pathway." MAPK, SRC, PDGFRa, ErbB, and EGFR were significantly regulated to correct these pathways. Kinases investigated by the literature on carcinoma were considered to be potential novel molecular therapeutic target in PTC and application of corresponding kinase inhibitors could be possible therapeutic tool. Conclusion. SRC, MAPK, and EGFR were the most important differentially expressed kinases in PTC. Combined inhibitors may have high efficacy in PTC treatment by targeting these kinases.
\end{abstract}

\section{Introduction}

Thyroid cancer, particularly papillary thyroid carcinoma, is considered to be one of the most common malignancies. Its incidence increases in differed geographic regions of the world in the past decade. Increase in incidence of thyroid cancer is one of the top malignancies in the United States [1]. Rise in incidence observed may partly be accounted for improvement in diagnosis. It is indicated that papillary thyroid carcinoma is attributed to the entire increase significantly by separated researches $[2,3]$. Although the thyroidectomy, thyroidstimulating hormone suppression therapy, and radioiodine remnant ablation (RAI) ameliorate the disease-free survival, a group of patients still cannot benefit from the traditional therapy. $5 \%$ of patients with distant metastasis are refractory to RAI [4]. It is believed that the tumor cells lost their ability in uptake of the iodide and side effects of ${ }^{131}$ I therapy of salivary gland dysfunction $(>40 \%)$, abnormally dry eyes $(25 \%)$, and transient fertility reduction $(20 \%)$ affect the patient living quality seriously [5]. Besides, patients are contraindicated to thyroidectomy who suffer from cardiac or respiratory disease, dialysis-dependent renal failure, anticoagulant therapy, obstructive sleep apnea, mental impairment, thyrotoxicosis, and morbid obesity [6]. The postoperative complications of surgery are quite common including hypocalcemia $(20 \%-30 \%)$ and recurrent laryngeal nerve injury (5\%-11\%) and risk for nerve injury increased significantly by reoperation [7]. Due to the limits of traditional therapy, more efforts are recalled for new drugs development with higher efficiency and fewer side effects. It is protein kinases that function as core in signaling pathways participating in tumor proliferation, invasion, metastasis, and tumor microenvironment formation in major types of tumors, including thyroid cancer pathogenesis.

It has been identified that in papillary thyroid carcinoma several molecular changes exist: rearranged during transfection (RET)/papillary thyroid carcinoma gene rearrangements, $\mathrm{BRAF}$ (B-RAF protooncogene, serine/threonine kinase) gene mutations, RAS (rat sarcoma) mutations, and vascular endothelial growth factor receptor 2 angiogenesis 
pathways activation. BRAF oncogene mutation occurred in approximately $45 \%$ to $70 \%$ of patients with papillary thyroid carcinoma and VEGF overexpression is frequently found in tumors that originated in the thyroid [8-11]. In the landmark DECISION study, Sorafenib, a multikinase inhibitor of RET/RAS/RAF pathway, VEGF receptors 2 and 3, improved the progression-free survival by 3 months, from 5.8 months to 10.8 months, compared with placebo [12]. It emerged as a potentially effective option and approved by Food and Drug Administration (FDA) as a receptor tyrosine kinase inhibitor as treatment of differentiated thyroid cancer refractory to RAI.

We aimed to investigate the protein kinase expression difference between papillary thyroid carcinoma and normal thyroid and possible molecular mechanisms underlying PTC. We try to provide valuable information on PTC associated protein kinases for potential therapeutic targets.

\section{Method}

2.1. Identify Differentially Expressed Protein Kinases in PTC. We searched in the NCBI (National Center for Biotechnology Information) Gene Expression Omnibus (GEO) database (https:/www.ncbi.nlm.nih.gov/geo/) to retrieve the genomewide expression profile of human papillary thyroid carcinoma. The original dataset from GSE27155 including 51 human specimens of PTC and 4 specimens of normal thyroid tissues was downloaded and array from the Affymetrix platform was processed. To discover the differential gene expression the significance analysis of microarrays (SAM) was applied. False discovery rate (FDR) less than 0.05 was considered to present significant difference. All the differentially expressed genes were mapped onto The Human Protein Kinase Reference Database to establish differentially expressed kinases in PTC. Then we conducted systematic screening of the literature in PubMed for researches concerning the association between papillary thyroid carcinoma and protein kinases.

\subsection{Database-Based GO and Pathway Enrichment Analysis} and Literature Review. Each protein kinase's corresponding GO term or ID in the GO database was validated by AmiGO search engine. Gene ontology (GO) enrichment analysis was used to evaluate the potential function for the differentially expressed genes. The pathway was analyzed by the Kyoto Encyclopedia of Genes and Genomes (KEGG) database. To obtain putatively valuable new kinase targets for the treatment of PTC, we conducted a systematic literature screening of all the protein kinases. The keywords in the title and abstracts "each protein kinase," "cancer," and "papillary thyroid carcinoma" were used. Finally, we drew the picture of interactions among kinases, signaling pathways, and GO terms.

\subsection{Screening Kinase Inhibitors for Predicted Kinases Involved} in PTC. To obtain new potentially valuable kinase inhibitors for PTC therapy, we systematically screened all available multikinase and specific kinase inhibitors (http://www .selleckchem.com/). We than retrieved the number of publications related to each kinase inhibitor and carcinoma.

\section{Results}

3.1. Establishment of Differentially Expressed Protein Kinases. There are 518 human protein kinases in total in the protein kinase database. Amongst them, 110 kinases were predicted to be related to papillary thyroid carcinoma in our network. We tried to delineate a network of protein kinases engaged in PTC. Several kinase families exhibited correlation to pathophysiological process of PTC via the GO database. Here, we presented a map of these kinases to visualize their relationship in biological process.

3.2. Functional Analysis and Literature Review. GO and KEGG enrichment analyses were conducted in the differentially expressed kinases. Kinases with a result of less than 0.05 in GO terms and pathways with FDR-value were considered to be the most valuable possible targets and were applied for further analysis. Study in different kinds of cancer mainly focused on the roles of SRC ( $\mathrm{v}$-src sarcoma (Schmidt-Ruppin A-2) viral oncogene homolog (avian)), MAPK (mitogenactivated protein kinase), MET (met protooncogene (hepatocyte growth factor receptor)), ATM (ataxia telangiectasia mutated), PDGFRa (platelet-derived growth factor receptor, alpha polypeptide), ErbB (v-erb-a erythroblastic leukemia viral oncogene homolog), MAP2 K1 (bromodomain containing 4), TGFbR1 (transforming growth factor, beta receptor 1), and CDK6 (cyclin-dependent kinase 6) (shown in Figure 1). Coincidently, the above-predicted kinases were confirmed with differentially protein kinases expression investigated in PTC patients (Figure 2). 39 GO terms were annotated and presented as common biological process among all these kinases (Table 1). Finally, we built networks to investigate the relationship among kinases, signaling pathways, and GO terms (Figures 3 and 4).

3.3. Potential Novel Kinase Inhibitors for PTC. To investigate novel kinase inhibitors for the treatment of PTC, we conducted a literature review of the cancer-related research including 20 focused kinases involved in our network. The publication number could indicate the extent of the research on kinase inhibitor use in cancer treatment (Table 2).

\section{Discussion}

Tyrosine kinases, classified as receptor tyrosine kinase (RTK) and nonreceptor tyrosine kinase (nRTK), are essential mediators of signaling pathways through catalyzing phosphorylation of selecting tyrosine residues with ATP, leading to cell proliferation differentiation, migration, and metabolism. Recently, it has come in vogue to use tyrosine kinases inhibitors as conceivable anticancer drug and several tyrosine kinase inhibitors (TKIs) have been approved by FDA in neoplastic human disease, particularly in the thyroid cancer. The largest subfamily of nRTKs, Src family kinase (SFK), was closely related to PTC indicated by our network. It has been 


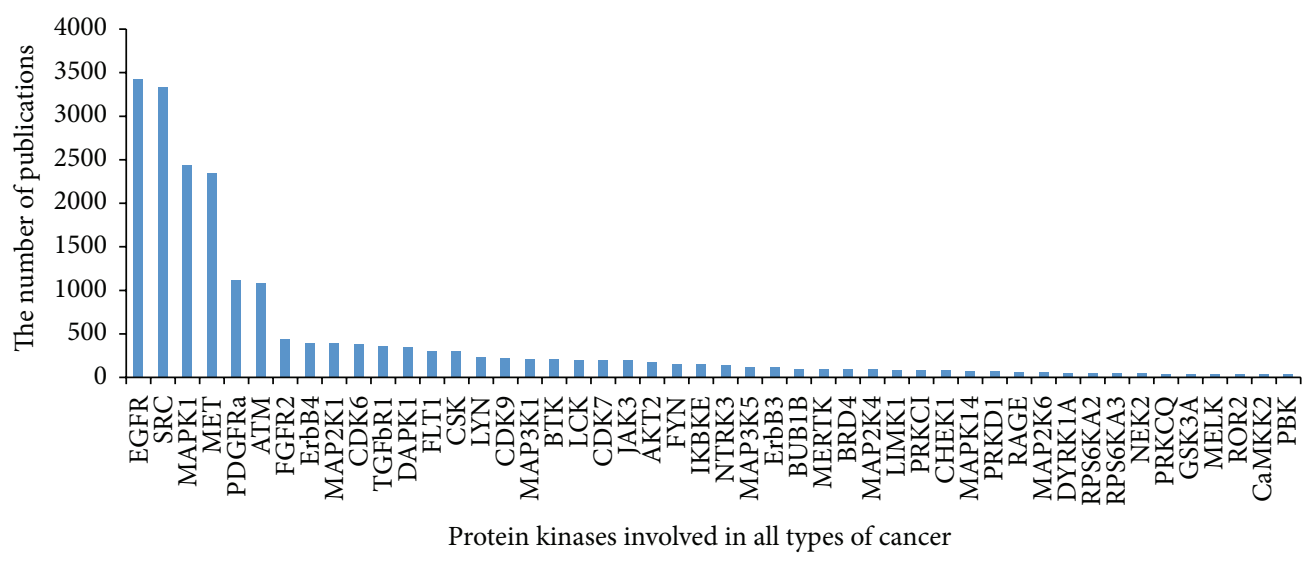

Figure 1

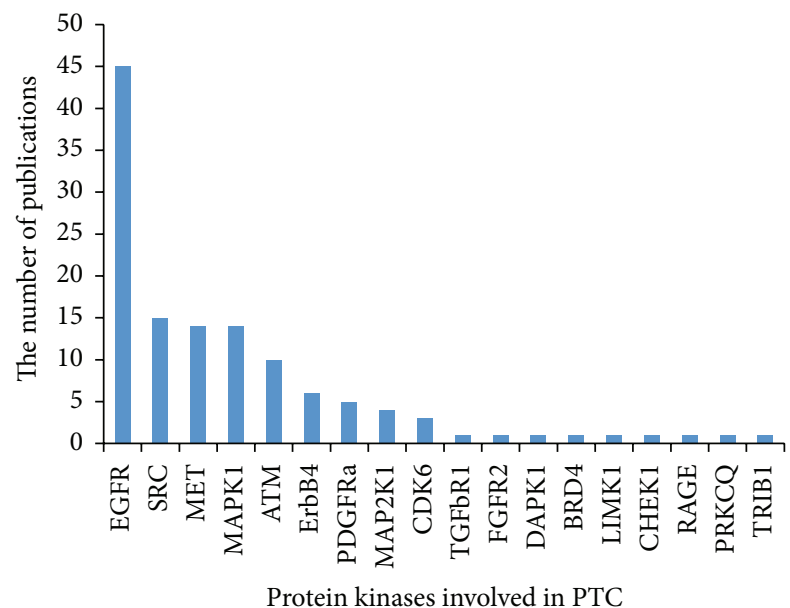

FIGURE 2

found that Src and Lyn are expressed in thyroid cancer cells and Src is overexpressed and activated in thyroid cancer [13]. Src also plays an important role in tumor metastasis due to its function in regulation of cytoskeleton, cell migration, adhesion, and invasion through phosphorylation of focal adhesion kinase (FAK), a component of focal adhesion complexes [14-16]. BTK and HCK expressions are upregulated in invasive thyroid cancer compared to matched normal group, which is similar to Src. Dasatinib, a FDA-approved SFK inhibitor, can block PTC tumor growth by more than $90 \%$ and significantly inhibited metastasis [13]. Apart from Src family, several kinase families were also annotated in the GO analysis: Bruton agammaglobulinemia tyrosine kinase (BTK), Janus Kinase 3 (JAK3), and c-src tyrosine kinase (CSK). However, the role of theses kinase families in PTC has not been reported yet and requires further elucidation.

It is epidermal growth factor family member, one of the receptor tyrosine kinase (RTK) families, that not only induces cell growth but also contributes to cell migration and proliferation via its downstream signaling pathways such as mitogenactivated protein kinase (MAPK) and phosphoinositide 3kinase (PI3K)/AKT pathways, which leads to cell migration, adhesion, and proliferation [17]. Several independent studies documented that EGFR mRNA expression is increased in PTC compared with benign thyroid lesions and EGFR protein expression is upregulated simultaneously [18-21]. Besides, EGFR expression was noted to possess prognostic value for that its expression was significantly associated with lymph node metastasis in a retrospective analysis of 168 patients with PTC [22]. Platelet-derived growth factor (PDGF)/PDGF receptor (PDGFR) system, another member of RTK class III, contributes to tumor formation, cell survival, growth, and proliferation [23-25]. Previous studies presented that PDGFR- $\alpha$ was upregulated at both mRNA and protein levels in thyroid carcinoma cell lines compared with benign tissues of thyroid nodular hyperplasia [25]. It was revealed that association of PDGFR- $\alpha$ with aggressive and lymph node metastatic phenotype in PTC was achieved through both the MAPK/ERK and PI3K/Akt pathways [26].

MET gene is one of the useful molecular markers for PTC [27] and elevated at RNA and protein level in frozen thyroid tissue samples and fine-needle aspiration biopsy [28]. However, no expression of c-met and its ligand hepatocyte growth factor/scatter factor (HGF/SF) could be detected in normal thyroid tissue [29]. MET could strengthen malignancy by its interaction with vascular endothelial growth factor receptor (VEGFR) which induces angiogenesis [30]. In the past decade, several MET kinase inhibitors have been developed, for example, the Tivantinib. Tivantinib impedes ligand-mediated MET autophosphorylation to reduce invasion, metastasis, and proliferation [31, 32]. Several Phase II trials on Tivantinib have been in process treating different tumor types, in which Tivantinib treatment showed antitumor effects with monotherapy in microphthalmia transcription factor family associated tumors [33] and prolonged progression-free survival in nonsmall-cell lung cancer [34]. MET may also be exhibited to be overexpressed in PTC with extremely limited investigation done in thyroid carcinoma. Cabozantinib is another FDA-approved tyrosine kinase inhibitor targeting three important pathways: MET, vascular endothelial growth factor (VEGF), and rearranged during transfection (RET) for the treatment of metastatic medullary thyroid cancer. It has shown significant effects 


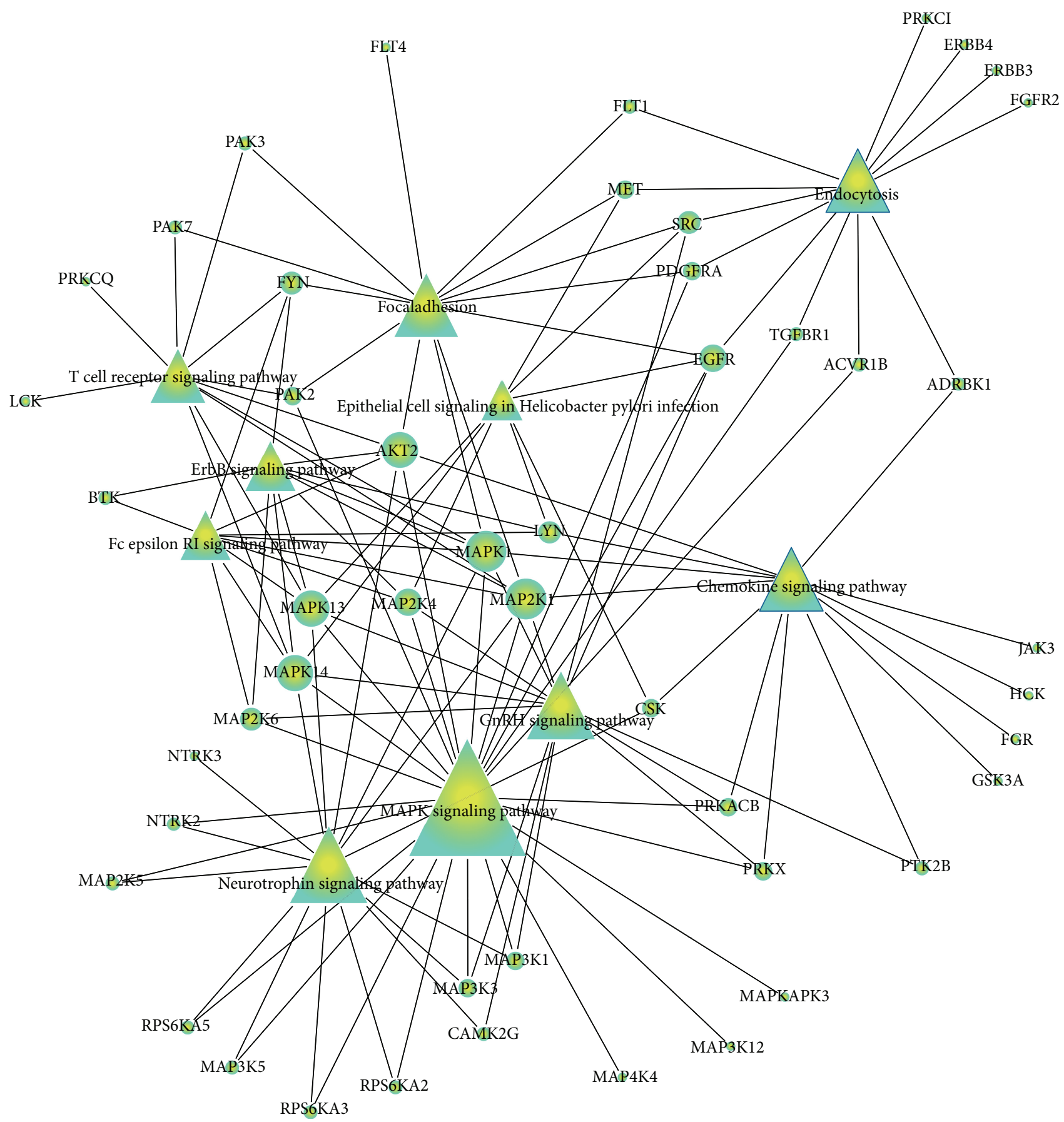

FIgURE 3: Kinases to pathway interactions network in PTC.

in prolongation of progression-free survival with acceptable safety profile [35]. Based on the above trials, inhibiting of MET pathway (or in combination with other kinase inhibitors) is quite a possible way to improve the prognosis of PTC.

Mitogen-activated protein kinase (MAPK) is regarded as a member of serine/threonine protein kinases and a canonical pathway activated by BRAF, RET, or TRK and RAS mutations through Ras-Raf-MEK-ERK cascade in PTCs [3638]. MAPK members act as key regulators for cell growth, proliferation, and differentiation during cancer progression.
Previous studies have reported that matrix metalloproteinases (MMPs) were modulated according to the intensity of MAPK pathway activation which partly explained the mechanism of increased propensity of tumor invasion in PTC patients carrying BRAF mutation [39, 40]. The phosphorylation status of MAPK molecule, p38 MAPK signaling pathway, could be achieved by high expression of family with sequence similarity 172 , member A (FAM172A) in human PTC which induced cell proliferation. However, the effects following MAPK molecule phosphorylation can be 


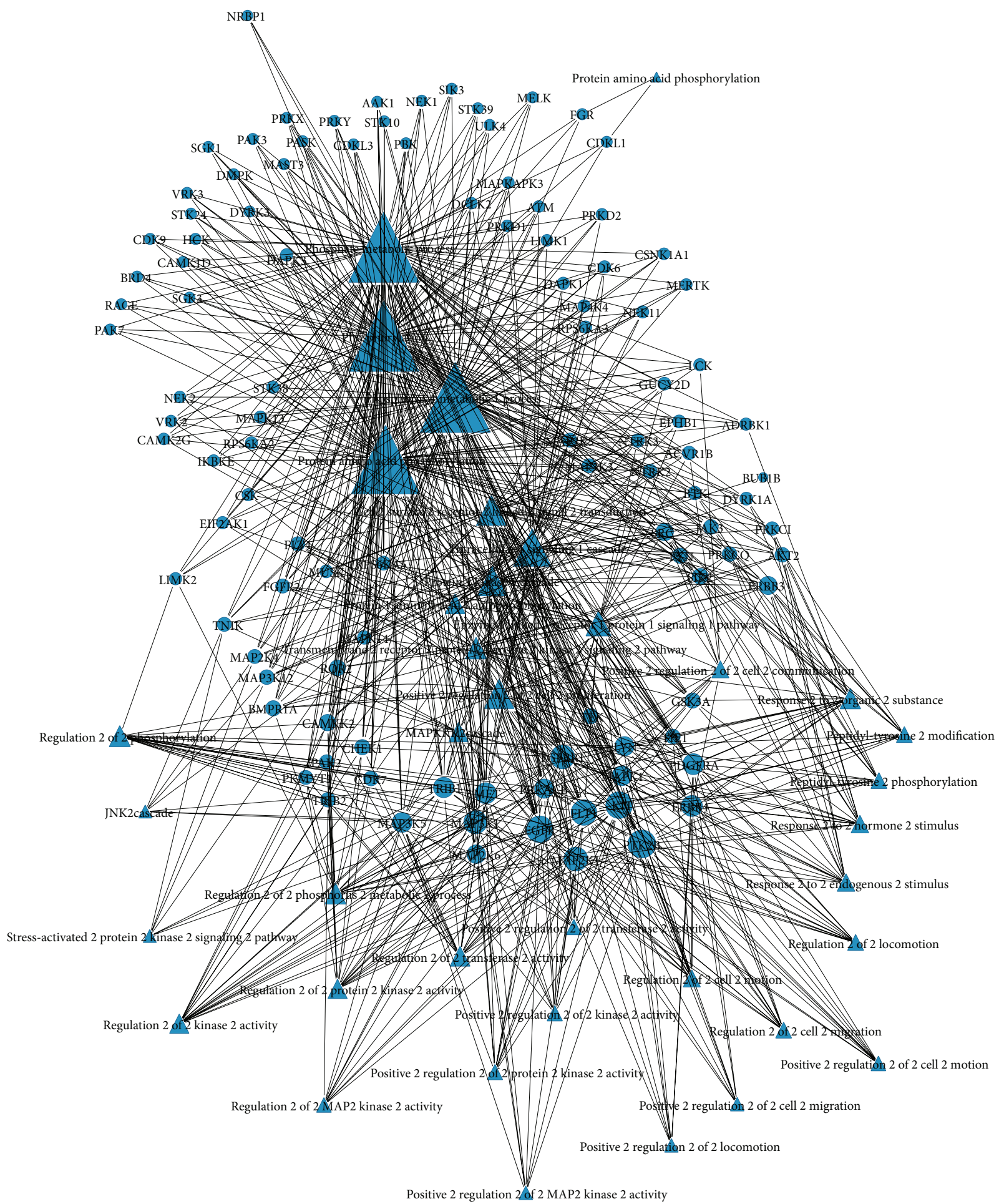

FIgURE 4: Kinases and GO network in PTC.

attenuated markedly by inhibitor of p38 MAPK, SB202190 [41]. Other two types of the mitogen-activated protein kinase (MAPK) cascade, namely, MAPK kinase (MAPKK/MEK) and MAPK kinase kinase (MAPKKK/MEKK) which play important roles in cell growth, were included in our network. It is well known that these two upstream molecules of MAPKs regulate cell proliferation and apoptosis by activating MAPK pathways [42]. Strikingly, inhibitors of MEK (PD0325901) may also contribute to restoration of tumor cells RAI uptake by recovery expression of $\mathrm{Na}^{+} / \mathrm{I}^{-}$symporter (NIS) protein [43]. The propensity of maintaining stability of NIS by MEK was proved again in human breast cancers [44]. 
TABLE 1: The functions of the most discussed protein kinases involved in PTC.

\begin{tabular}{|c|c|}
\hline Function & Kinases \\
\hline $\begin{array}{l}\text { Protein amino acid } \\
\text { phosphorylation }\end{array}$ & $\begin{array}{l}\text { EGFR, MAPK1, MEK, MEKK, MEKKK, } \\
\text { CDKL1, PDGFRA, FGFR2, ERBB4, } \\
\text { ERBB3, SRC, TGFBR1, MET, ATM, CSK, } \\
\text { LYN, CDK9, CDK6, CDK7, LCK, HCK, } \\
\text { FLT4, FYN, JAK3 }\end{array}$ \\
\hline Phosphorylation & $\begin{array}{l}\text { BTK, MEKKK, MEKK, EGFR, MAPK1, } \\
\text { PDGFRA, FGFR2, ERBB4, ERBB3, } \\
\text { EPHB1, SRC, TGFBR1, MET, ATM, CSK, } \\
\text { CDK6, LCK, HCK }\end{array}$ \\
\hline $\begin{array}{l}\text { Phosphorus } \\
\text { metabolic process }\end{array}$ & $\begin{array}{l}\text { BTK, MEK, MEKK, EGFR, MAPK1 } \\
\text { PDGFRA, FGFR2, ERBB4, ERBB3, } \\
\text { EPHB1, SRC, TGFBR1, MET, ATM, CSK, } \\
\text { LYN, CDK6, LCK, FYN, JAK3 }\end{array}$ \\
\hline $\begin{array}{l}\text { Phosphate metabolic } \\
\text { process }\end{array}$ & $\begin{array}{l}\text { BTK, MEKK, MEK, EGFR, MAPK, } \\
\text { PDGFRA, FGFR2, FGR, ERBB4, ERBB3, } \\
\text { EPHB1, SRC, TGFBR1, MET, ATM, } \\
\text { NTRK3, NTRK2, DYRK1A, CSK, LYN, } \\
\text { CDK9, CDK6, CDK7, LCK, HCK, FYN } \\
\text { JAK3 }\end{array}$ \\
\hline $\begin{array}{l}\text { Protein kinase } \\
\text { cascade }\end{array}$ & $\begin{array}{l}\text { ERBB3, SRC, BTK, MEKK, MEK, EGFR, } \\
\text { TGFBR1, MET, MAPK, FYN, JAK3 }\end{array}$ \\
\hline $\begin{array}{l}\text { Intracellular signaling } \\
\text { cascade }\end{array}$ & $\begin{array}{l}\text { BTK, MEKK, CSK, MEK, EGFR, LYN, } \\
\text { CDK, MEKKK, MAPK1, ERBB3, SRC, } \\
\text { TGFBR1, MET, ATM, FYN, JAK3 }\end{array}$ \\
\hline $\begin{array}{l}\text { Protein amino acid } \\
\text { autophosphorylation }\end{array}$ & $\begin{array}{l}\text { EGFR, TGFBR1, MET, MEKK, FYN, } \\
\text { PDGFRA }\end{array}$ \\
\hline $\begin{array}{l}\text { Enzyme linked } \\
\text { receptor protein } \\
\text { signaling pathway }\end{array}$ & $\begin{array}{l}\text { FGFR2, ERBB4, ERBB3, SRC, EPHB1, } \\
\text { MEKK, AKT2, EGFR, TGFBR1, MET } \\
\text { PDGFRA, JAK3 }\end{array}$ \\
\hline $\begin{array}{l}\text { Transmembrane } \\
\text { receptor protein } \\
\text { tyrosine kinase } \\
\text { signaling pathway }\end{array}$ & $\begin{array}{l}\text { EGFR, FGFR2, ERBB4, ERBB3, MET, } \\
\text { SRC, EPHB1, PDGFRA, AKT2 }\end{array}$ \\
\hline $\begin{array}{l}\text { Peptidyl-tyrosine } \\
\text { phosphorylation }\end{array}$ & $\begin{array}{l}\text { ERBB4, LYN, ERBB3, FYN, PDGFRA, } \\
\text { JAK3, SRC, BTK }\end{array}$ \\
\hline MAPKKK cascade & $\begin{array}{l}\text { EGFR, MEK, TGFBR1, MET, MAPK, } \\
\text { MEKK }\end{array}$ \\
\hline $\begin{array}{l}\text { Peptidyl-tyrosine } \\
\text { modification }\end{array}$ & $\begin{array}{l}\text { ERBB4, LYN, ERBB3, FYN, PDGFRA, } \\
\text { JAK3, SRC, BTK }\end{array}$ \\
\hline $\begin{array}{l}\text { Regulation of } \\
\text { phosphorylation }\end{array}$ & $\begin{array}{l}\text { EGFR, MEK, LYN, TGFBR1, MET, CDK7, } \\
\text { MEKK }\end{array}$ \\
\hline $\begin{array}{l}\text { Regulation of } \\
\text { transferase activity }\end{array}$ & $\begin{array}{l}\text { EGFR, MEK, TGFBR1, MET, CDK7, } \\
\text { MEKK }\end{array}$ \\
\hline $\begin{array}{l}\text { Regulation of } \\
\text { phosphate metabolic } \\
\text { process }\end{array}$ & $\begin{array}{l}\text { EGFR, MEK, LYN, TGFBR1, MET, CDK, } \\
\text { MEKK }\end{array}$ \\
\hline $\begin{array}{l}\text { Regulation of } \\
\text { phosphorus } \\
\text { metabolic process }\end{array}$ & $\begin{array}{l}\text { EGFR, MEK, LYN, TGFBR1, MET, CDK, } \\
\text { MEKK }\end{array}$ \\
\hline $\begin{array}{l}\text { Regulation of protein } \\
\text { kinase activity }\end{array}$ & $\begin{array}{l}\text { EGFR, MAP2K1, TGFBR1, MET, CDK7, } \\
\text { MAP3K5, MAP3K1, MAP2K6 }\end{array}$ \\
\hline $\begin{array}{l}\text { Regulation of kinase } \\
\text { activity }\end{array}$ & $\begin{array}{l}\text { EGFR, MAP2K1, TGFBR1, MET, CDK7, } \\
\text { MAP3K5, MAP3K1, MAP2K6 }\end{array}$ \\
\hline $\begin{array}{l}\text { Regulation of cell } \\
\text { motion }\end{array}$ & $\begin{array}{l}\text { EGFR, LYN, MAP2K1, ERBB4, TGFBR1, } \\
\text { MAPK1, MAP3K1, PDGFRA, }\end{array}$ \\
\hline $\begin{array}{l}\text { Positive regulation of } \\
\text { cell motion }\end{array}$ & $\begin{array}{l}\text { EGFR, MAPK1, ERBB4, MAP2K1, LYN, } \\
\text { TGFBR1, PDGFRA, }\end{array}$ \\
\hline
\end{tabular}

TABLE 1: Continued.

\begin{tabular}{|c|c|}
\hline Function & Kinases \\
\hline $\begin{array}{l}\text { Regulation of cell } \\
\text { migration }\end{array}$ & $\begin{array}{l}\text { EGFR, MAPK1, ERBB4, MAP2K1, } \\
\text { MAP3K1, PDGFRA, }\end{array}$ \\
\hline $\begin{array}{l}\text { Cell surface receptor } \\
\text { linked signal } \\
\text { transduction }\end{array}$ & $\begin{array}{l}\text { FGFR2, ERBB4, ERBB3, SRC, EPHB1, } \\
\text { MAP3K1, TEK, EGFR, LYN, TGFBR1, } \\
\text { MET, MAPK1, FYN, MAPK14, LCK, } \\
\text { PDGFRA, JAK3 }\end{array}$ \\
\hline $\begin{array}{l}\text { Regulation of } \\
\text { locomotion }\end{array}$ & $\begin{array}{l}\text { EGFR, MAPK1, ERBB4, MAP2K1, } \\
\text { MAP3K1, PDGFRA }\end{array}$ \\
\hline $\begin{array}{l}\text { Response to hormone } \\
\text { stimulus }\end{array}$ & $\begin{array}{l}\text { ERBB4, MAP2K1, LYN, ERBB3, TGFBR1, } \\
\text { SRC, MAPK1, PDGFRA }\end{array}$ \\
\hline $\begin{array}{l}\text { Regulation of MAP } \\
\text { kinase activity }\end{array}$ & $\begin{array}{l}\text { EGFR, MAP3K5, MAP2K1, MAP3K1, } \\
\text { MET, MAP2K6 }\end{array}$ \\
\hline $\begin{array}{l}\text { Positive regulation of } \\
\text { cell communication }\end{array}$ & $\begin{array}{l}\text { EGFR, LYN, ERBB4, ERBB3, TGFBR1, } \\
\text { SRC, MAP3K3, LCK }\end{array}$ \\
\hline $\begin{array}{l}\text { Regulation of cell } \\
\text { proliferation }\end{array}$ & $\begin{array}{l}\text { EGFR, FGFR2, ERBB4, LYN, ERBB3, } \\
\text { TGFBR1, CDK6, MAPK1, PDGFRA, } \\
\text { CSK, MAP2K5 }\end{array}$ \\
\hline $\begin{array}{l}\text { Response to organic } \\
\text { substance }\end{array}$ & $\begin{array}{l}\text { EGFR, ERBB4, MAP2K1, LYN, ERBB3, } \\
\text { TGFBR1, SRC, MAPK1, FYN, MAPK14, } \\
\text { PDGFRA }\end{array}$ \\
\hline $\begin{array}{l}\text { Response to } \\
\text { endogenous stimulus }\end{array}$ & $\begin{array}{l}\text { ERBB4, MAP2K1, LYN, ERBB3, TGFBR1, } \\
\text { SRC, MAPK1, PDGFRA }\end{array}$ \\
\hline $\begin{array}{l}\text { Positive regulation of } \\
\text { cell proliferation }\end{array}$ & $\begin{array}{l}\text { EGFR, FGFR2, ERBB4, LYN, TGFBR1, } \\
\text { CDK6, MAPK1, PDGFRA, MAP2K5 }\end{array}$ \\
\hline $\begin{array}{l}\text { Positive regulation of } \\
\text { cell migration }\end{array}$ & $\begin{array}{l}\text { EGFR, MAPK1, ERBB4, MAP2K1, } \\
\text { PDGFRA, }\end{array}$ \\
\hline JNK cascade & MAP3К5, MAP3К1, MAP2K4, MAР3К12 \\
\hline $\begin{array}{l}\text { Stress-activated } \\
\text { protein kinase } \\
\text { signaling pathway }\end{array}$ & MAP3K5, MAP3K1, MA \\
\hline $\begin{array}{l}\text { Positive regulation of } \\
\text { protein kinase activity }\end{array}$ & $\begin{array}{l}\text { EGFR, MAP3K5, MAP2K1, MAP3K1, } \\
\text { TGFBR1, MET, MAP2K6 }\end{array}$ \\
\hline $\begin{array}{l}\text { Positive regulation of } \\
\text { locomotion }\end{array}$ & $\begin{array}{l}\text { EGFR, MAPK1, ERBB4, MAP2K1, } \\
\text { PDGFRA }\end{array}$ \\
\hline $\begin{array}{l}\text { Positive regulation of } \\
\text { kinase activity }\end{array}$ & $\begin{array}{l}\text { EGFR, MAP3K5, MAP2K1, MAP3K1, } \\
\text { TGFBR1, MET, MAP2K6 }\end{array}$ \\
\hline $\begin{array}{l}\text { Positive regulation of } \\
\text { MAP kinase activity }\end{array}$ & $\begin{array}{l}\text { EGFR, MAP3K5, MAP2K1, MAP3K1, } \\
\text { MET, MAP2K6 }\end{array}$ \\
\hline $\begin{array}{l}\text { Positive regulation of } \\
\text { transferase activity }\end{array}$ & $\begin{array}{l}\text { EGFR, MAP3K5, MAP2K1, MAP3K1, } \\
\text { TGFBR1, MET, MAP2K6 }\end{array}$ \\
\hline
\end{tabular}

Tumors are characterized for uncontrolled cell division. Cyclin-dependent kinases (CDKs) responsible for controlling cell cycle were expected to become an effective therapeutic target. Various evidences point to a crucial role of an aberrant cyclin D1-CDK4/6 complex in initiation and progression of cancers. Cyclin D1 expressed in about 30\% of PTC carcinoma [45] and its overexpression correlate with metastasis of PTC [46]. P2 $7^{\mathrm{KIPl}}$, a CDK inhibitor that could impair the activity of cyclin-CDK complex, was found to be reduced in metastatic forms of PTC $[47,48]$. Therefore, CDKs are attractive set of targets for novel anticancer drug development.

To conclude, protein kinases play essential roles in controlling cellular growth, cell proliferation, and cell death and have been found to participate in human neoplastic diseases. Our network presented potential kinases involved in 
TABLE 2: Potential novel kinase inhibitors for the treatment of PTC.

\begin{tabular}{|c|c|c|}
\hline Kinase & Kinase inhibitor & $\begin{array}{c}\text { Publication } \\
\text { number }\end{array}$ \\
\hline \multirow{25}{*}{ EGFR } & Gefitinib (ZD1839) & 3040 \\
\hline & Erlotinib $\mathrm{HCl}$ (OSI-744) & 4310 \\
\hline & Lapatinib & 1681 \\
\hline & Afatinib (BIBW2992) & 409 \\
\hline & AZD8931 (Sapitinib) & 389 \\
\hline & AG-1478 (Tyrphostin AG-1478) & 273 \\
\hline & AG-490 (Tyrphostin B42) & 221 \\
\hline & $\mathrm{PD} 153035 \mathrm{HCl}$ & 136 \\
\hline & Neratinib (HKI-272) & 113 \\
\hline & Canertinib (CI-1033) & 94 \\
\hline & Icotinib & 69 \\
\hline & AEE788 (NVP-AEE788) & 61 \\
\hline & Pelitinib (EKB-569) & 43 \\
\hline & Varlitinib & 32 \\
\hline & OSI-420 & 31 \\
\hline & PD168393 & 24 \\
\hline & Rociletinib (CO-1686, AVL-301) & 23 \\
\hline & WZ4002 & 18 \\
\hline & WHI-P154 & 15 \\
\hline & CUDC-101 & 13 \\
\hline & TAK-285 & 12 \\
\hline & Tyrphostin 9 & 8 \\
\hline & AST-1306 & 5 \\
\hline & CL-387785 (EKI-785) & 5 \\
\hline & AG-18 & 2 \\
\hline \multirow{8}{*}{ SRC } & Dasatinib & 1771 \\
\hline & PP2 & 345 \\
\hline & Bosutinib (SKI-606) & 207 \\
\hline & Saracatinib (AZD0530) & 126 \\
\hline & SU6656 & 64 \\
\hline & KX2-391 & 8 \\
\hline & NVP-BHG712 & 2 \\
\hline & Dasatinib Monohydrate & 2 \\
\hline MAPK & BMS-536924 & 29 \\
\hline \multirow{5}{*}{ MET } & SU11274 & 98 \\
\hline & Foretinib (GSK1363089) & 26 \\
\hline & SGX-523 & 7 \\
\hline & NPS-1034 & 2 \\
\hline & NVP-BVU972 & 2 \\
\hline \multirow{3}{*}{ ATM } & AZD8055 & 66 \\
\hline & KU-55933 (ATM Kinase Inhibitor) & 42 \\
\hline & KU-60019 & 9 \\
\hline \multirow{4}{*}{ CDK6 } & Flavopiridol (Alvocidib) $\mathrm{HCl}$ & 374 \\
\hline & PD-0332991 & 137 \\
\hline & LY2835219 & 9 \\
\hline & LDC000067 & 1 \\
\hline
\end{tabular}

TABle 2: Continued.

\begin{tabular}{lcc}
\hline Kinase & Kinase inhibitor & $\begin{array}{c}\text { Publication } \\
\text { number }\end{array}$ \\
\hline \multirow{4}{*}{ TGFbR1 } & SB431542 & 114 \\
& SD-208 & 25 \\
& SB505124 & 10 \\
EW-7197 & 8 \\
SB525334 & 6 \\
D 4476 & 2 \\
RepSox & 1 \\
GW788388 & 1 \\
\hline PDGFRa & Imatinib (STI571) & 6749 \\
& Ponatinib (AP24534) & 192 \\
& Nintedanib (BIBF 1120) & 102 \\
Masitinib (AB1010) & 52 \\
Lenvatinib (E7080) & 28 \\
\hline Quizartinib (AC220) & 24 \\
& Crenolanib (CP-868596) & 19 \\
& Amuvatinib (MP-470) & 13 \\
ENMD-2076 & 12 \\
Telatinib & 11 \\
& OSI-930 & 8 \\
CP-673451 & 5 \\
\hline & AZD8931 (Sapitinib) & 12 \\
\hline & & \\
& &
\end{tabular}

several aspects of papillary thyroid carcinoma development including invasion, metastasis, progression, and sensitivity to RAI. Many of the kinase inhibitors are undergoing clinical trials while several have already been approved for treatment of PTC and/or other types of cancer. In addition to the traditional kinases applied in PTC, we provided more kinases which have not been equivocally investigated but are potentially effective options in the treatment of PTC. Therefore, targeting abnormal activation of tyrosine kinases is a promising way to treat PTC.

\section{Competing Interests}

The authors declare that they have no competing interests.

\section{Acknowledgments}

This study was supported by Harbin Medical University Postgraduate Innovative Research Projects (Grant no. YJSCX2015-19HYD).

\section{References}

[1] R. Siegel, C. DeSantis, K. Virgo et al., "Cancer treatment and survivorship statistics, 2012," CA: A Cancer Journal for Clinicians, vol. 62, no. 4, pp. 220-241, 2012.

[2] L. Davies and H. G. Welch, "Current thyroid cancer trends in the United States," JAMA Otolaryngology-Head \& Neck Surgery, vol. 140, no. 4, pp. 317-322, 2014. 
[3] L. Vučemilo, T. Znaor, T. Kuliš, M. Šekerija, and A. Znaor, "Thyroid cancer incidence and mortality trends in Croatia 1988-2010," Acta Clinica Croatica, vol. 54, no. 1, pp. 30-37, 2015.

[4] P. Fallahi, V. Mazzi, R. Vita et al., "New therapies for dedifferentiated papillary thyroid cancer," International Journal of Molecular Sciences, vol. 16, no. 3, pp. 6153-6182, 2015.

[5] N. G. Iyer, L. G. T. Morris, R. M. Tuttle, A. R. Shaha, and I. Ganly, "Rising incidence of second cancers in patients with low-risk (T1N0) thyroid cancer who receive radioactive iodine therapy," Cancer, vol. 117, no. 19, pp. 4439-4446, 2011.

[6] D. J. Terris, S. Snyder, D. Carneiro-Pla et al., "American thyroid association statement on outpatient thyroidectomy," Thyroid, vol. 23, no. 10, pp. 1193-1202, 2013.

[7] N. Christou and M. Mathonnet, "Complications after total thyroidectomy," Journal of Visceral Surgery, vol. 150, no. 4, pp. 249-256, 2013.

[8] Y. Cohen, M. Xing, E. Mambo et al., "BRAF mutation in papillary thyroid carcinoma," Journal of the National Cancer Institute, vol. 95, no. 8, pp. 625-627, 2003.

[9] Y. C. Henderson, T. D. Shellenberger, M. D. Williams et al., "High rate of BRAF and RET/PTC dual mutations associated with recurrent papillary thyroid carcinoma," Clinical Cancer Research, vol. 15, no. 2, pp. 485-491, 2009.

[10] G. Riesco-Eizaguirre, P. Gutierrez-Martinez, M. A. GarciaCabezas, M. Nistal, and P. Santisteban, "The oncogene BRAF $\mathrm{V} 600 \mathrm{E}$ is associated with a high risk of recurrence and less differentiated papillary thyroid carcinoma due to the impairment of $\mathrm{Na}^{+} / \mathrm{I}^{-}$targeting to the membrane," Endocrine-Related Cancer, vol. 13, no. 1, pp. 257-269, 2006.

[11] M. E. Cabanillas, S. G. Waguespack, Y. Bronstein et al., "Treatment with tyrosine kinase inhibitors for patients with differentiated thyroid cancer: the M. D. Anderson experience," The Journal of Clinical Endocrinology \& Metabolism, vol. 95, no. 6, pp. 2588-2595, 2010.

[12] M. S. Brose, C. M. Nutting, B. Jarzab et al., "Sorafenib in radioactive iodine-refractory, locally advanced or metastatic differentiated thyroid cancer: a randomised, double-blind, phase 3 trial," The Lancet, vol. 384, no. 9940, pp. 319-328, 2014.

[13] C. M. Chan, X. Jing, L. A. Pike et al., "Targeted inhibition of Src kinase with dasatinib blocks thyroid cancer growth and metastasis," Clinical Cancer Research, vol. 18, no. 13, pp. 35803591, 2012.

[14] M. Guarino, "Src signaling in cancer invasion," Journal of Cellular Physiology, vol. 223, no. 1, pp. 14-26, 2010.

[15] T. J. Yeatman, "A renaissance for SRC," Nature Reviews Cancer, vol. 4, no. 6, pp. 470-480, 2004.

[16] M. P. Playford and M. D. Schaller, "The interplay between Src and integrins in normal and tumor biology," Oncogene, vol. 23, no. 48, pp. 7928-7946, 2004.

[17] J. C. Ricarte-Filho, M. Ryder, D. A. Chitale et al., "Mutational profile of advanced primary and metastatic radioactive iodinerefractory thyroid cancers reveals distinct pathogenetic roles for BRAF, PIK3CA, and AKT1," Cancer Research, vol. 69, no. 11, pp. 4885-4893, 2009.

[18] A. K.-Y. Lam, K. K.-P. Lau, V. Gopalan, J. Luk, and C. Y. Lo, "Quantitative analysis of the expression of TGF-alpha and EGFR in papillary thyroid carcinoma: clinicopathological relevance," Pathology, vol. 43, no. 1, pp. 40-47, 2011.

[19] K. Masago, R. Asato, S. Fujita et al., "Epidermal growth factor receptor gene mutations in papillary thyroid carcinoma," International Journal of Cancer, vol. 124, no. 11, pp. 2744-2749, 2009.
[20] M. Landriscina, G. Pannone, A. Piscazzi et al., "Epidermal growth factor receptor 1 expression is upregulated in undifferentiated thyroid carcinomas in humans," Thyroid, vol. 21, no. 11, pp. 1227-1234, 2011.

[21] S. Kato, T. Kobayashi, K. Yamada et al., "Expression of erbB receptors mRNA in thyroid tissues," Biochimica et Biophysica Acta (BBA)_General Subjects, vol. 1673, no. 3, pp. 194-200, 2004.

[22] Y. M. Lee and J. B. Lee, "Prognostic value of epidermal growth factor receptor, p53 and galectin-3 expression in papillary thyroid carcinoma," Journal of International Medical Research, vol. 41, no. 3, pp. 825-834, 2013.

[23] J. Homsi and A. I. Daud, "Spectrum of activity and mechanism of action of VEGF/PDGF inhibitors," Cancer Control, vol. 14, no. 3, pp. 285-294, 2007.

[24] J. Andrae, R. Gallini, and C. Betsholtz, "Role of plateletderived growth factors in physiology and medicine," Genes \& Development, vol. 22, no. 10, pp. 1276-1312, 2008.

[25] K.-T. Chen, J.-D. Lin, M.-J. Liou, H.-F. Weng, C. A. Chang, and E.-C. Chan, "An aberrant autocrine activation of the plateletderived growth factor $\alpha$-receptor in follicular and papillary thyroid carcinoma cell lines," Cancer Letters, vol. 231, no. 2, pp. 192-205, 2006.

[26] J. Zhang, P. Wang, M. Dykstra et al., "Platelet-derived growth factor receptor- $\alpha$ promotes lymphatic metastases in papillary thyroid cancer," The Journal of Pathology, vol. 228, no. 2, pp. 241250, 2012.

[27] K. Fujarewicz, M. Jarzab, M. Eszlinger et al., "A multi-gene approach to differentiate papillary thyroid carcinoma from benign lesions: gene selection using support vector machines with bootstrapping," Endocrine-Related Cancer, vol. 14, no. 3, pp. 809-826, 2007.

[28] C. A. T. da Silveira Mitteldorf, J. M. de Sousa-Canavez, K. R. M. Leite, C. Massumoto, and L. H. Camara-Lopes, "FN1, GALE, MET, and QPCT overexpression in papillary thyroid carcinoma: molecular analysis using frozen tissue and routine fineneedle aspiration biopsy samples," Diagnostic Cytopathology, vol. 39, no. 8, pp. 556-561, 2011.

[29] A. Gentile, L. Trusolino, and P. M. Comoglio, "The Met tyrosine kinase receptor in development and cancer," Cancer and Metastasis Reviews, vol. 27, no. 1, pp. 85-94, 2008.

[30] S. Pennacchietti, P. Michieli, M. Galluzzo, M. Mazzone, S. Giordano, and P. M. Comoglio, "Hypoxia promotes invasive growth by transcriptional activation of the met protooncogene," Cancer Cell, vol. 3, no. 4, pp. 347-361, 2003.

[31] S. Eathiraj, R. Palma, E. Volckova et al., "Discovery of a novel mode of protein kinase inhibition characterized by the mechanism of inhibition of human mesenchymal-epithelial transition factor (c-Met) protein autophosphorylation by ARQ 197," The Journal of Biological Chemistry, vol. 286, no. 23, pp. 20666-20676, 2011.

[32] N. Munshi, S. Jeay, Y. Li et al., "ARQ 197, a novel and selective inhibitor of the human c-Met receptor tyrosine kinase with antitumor activity," Molecular Cancer Therapeutics, vol. 9, no. 6, pp. 1544-1553, 2010.

[33] A. J. Wagner, J. M. Goldberg, S. G. Dubois et al., "Tivantinib (ARQ 197), a selective inhibitor of MET, in patients with microphthalmia transcription factor-associated tumors: results of a multicenter phase 2 trial," Cancer, vol. 118, no. 23, pp. 58945902, 2012.

[34] L. V. Sequist, J. von Pawel, E. G. Garmey et al., "Randomized phase II study of erlotinib plus tivantinib versus erlotinib 
plus placebo in previously treated non-small-cell lung cancer," Journal of Clinical Oncology, vol. 29, no. 24, pp. 3307-3315, 2011.

[35] J. Krajewska, T. Olczyk, and B. Jarzab, "Cabozantinib for the treatment of progressive metastatic medullary thyroid cancer," Expert Review of Clinical Pharmacology, vol. 9, no. 1, pp. 69-79, 2016.

[36] E. T. Kimura, M. N. Nikiforova, Z. Zhu, J. A. Knauf, Y. E. Nikiforov, and J. A. Fagin, "High prevalence of BRAF mutations in thyroid cancer: genetic evidence for constitutive activation of the RET/PTC-RAS-BRAF signaling pathway in papillary thyroid carcinoma," Cancer Research, vol. 63, no. 7, pp. 14541457, 2003.

[37] P. Soares, V. Trovisco, A. S. Rocha et al., "BRAF mutations and RET/PTC rearrangements are alternative events in the etiopathogenesis of PTC," Oncogene, vol. 22, no. 29, pp. 45784580, 2003.

[38] M. Frattini, C. Ferrario, P. Bressan et al., "Alternative mutations of BRAF, RET and NTRK1 are associated with similar but distinct gene expression patterns in papillary thyroid cancer," Oncogene, vol. 23, no. 44, pp. 7436-7440, 2004.

[39] C. Mesa Jr., M. Mirza, N. Mitsutake et al., "Conditional activation of RET/PTC3 and BRAFV600E in thyroid cells is associated with gene expression profiles that predict a preferential role of BRAF in extracellular matrix remodeling," Cancer Research, vol. 66, no. 13, pp. 6521-6529, 2006.

[40] I. Palona, H. Namba, N. Mitsutake et al., "BRAF ${ }^{\mathrm{V} 600 \mathrm{E}}$ promotes invasiveness of thyroid cancer cells through nuclear factor $\kappa \mathrm{B}$ activation," Endocrinology, vol. 147, no. 12, pp. 5699-5707, 2006.

[41] M.-F. Li, R. Zhang, M.-G. Guo et al., "FAM172A protein promotes the proliferation of human papillary thyroid carcinoma cells via the p38 mitogen-activated protein kinase pathway," Molecular Medicine Reports, vol. 13, no. 1, pp. 353-358, 2016.

[42] C. Bonvin, A. Guillon, M. X. Van Bemmelen, P. Gerwins, G. L. Johnson, and C. Widmann, "Role of the amino-terminal domains of MEKKs in the activation of NFKB and MAPK pathways and in the regulation of cell proliferation and apoptosis," Cellular Signalling, vol. 14, no. 2, pp. 123-131, 2002.

[43] D. Chakravarty, E. Santos, M. Ryder et al., "Small-molecule MAPK inhibitors restore radioiodine incorporation in mouse thyroid cancers with conditional BRAF activation," The Journal of Clinical Investigation, vol. 121, no. 12, pp. 4700-4711, 2011.

[44] Z. Zhang, S. Beyer, and S. M. Jhiang, "MEK inhibition leads to lysosome-mediated $\mathrm{Na}^{+} / \mathrm{I}^{-}$symporter protein degradation in human breast cancer cells," Endocrine-Related Cancer, vol. 20, no. 2, pp. 241-250, 2013.

[45] F. Basolo, M. A. Caligo, A. Pinchera et al., "Cyclin D1 overexpression in thyroid carcinomas: relation with clinico-pathological parameters, retinoblastoma gene product, and ki67 labeling index," Thyroid, vol. 10, no. 9, pp. 741-746, 2000.

[46] M. L. C. Khoo, N. J. P. Beasley, S. Ezzat, J. L. Freeman, and S. L. Asa, "Overexpression of cyclin D1 and underexpression of p27 predict lymph node metastases in papillary thyroid carcinoma," Journal of Clinical Endocrinology and Metabolism, vol. 87, no. 4, pp. 1814-1818, 2002.

[47] M. B. Resnick, P. Schacter, Y. Finkelstein, Y. Kellner, and O. Cohen, "Immunohistochemical analysis of p27/kip1 expression in thyroid carcinoma," Modern Pathology, vol. 11, no. 8, pp. 735739, 1998.

[48] L. A. Erickson, O. M. Yousef, L. Jin, C. M. Lohse, V. S. Pankratz, and R. V. Lloyd, "p27kip1 expression distinguishes papillary hyperplasia in Graves' disease from papillary thyroid carcinoma," Modern Pathology, vol. 13, no. 9, pp. 1014-1019, 2000. 


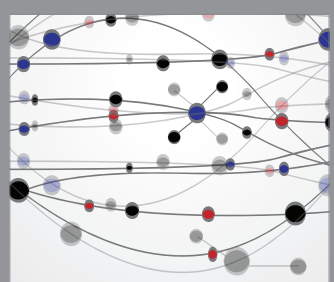

The Scientific World Journal
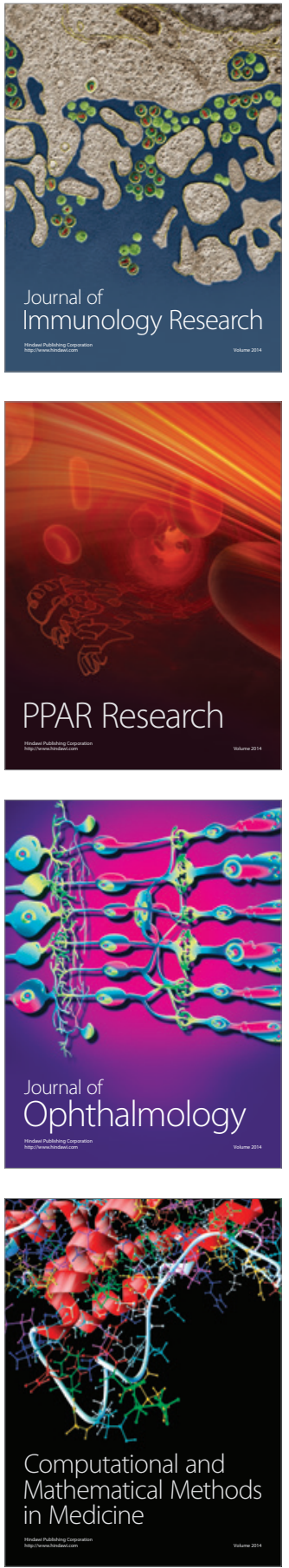

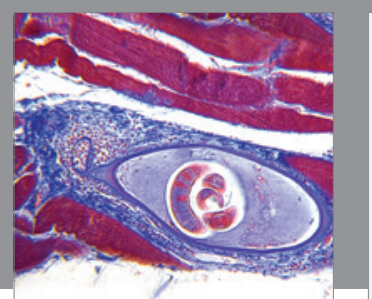

Gastroenterology Research and Practice

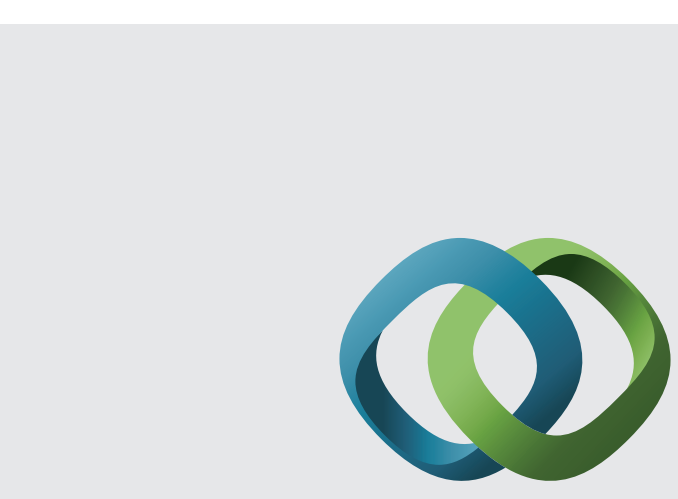

\section{Hindawi}

Submit your manuscripts at

http://www.hindawi.com
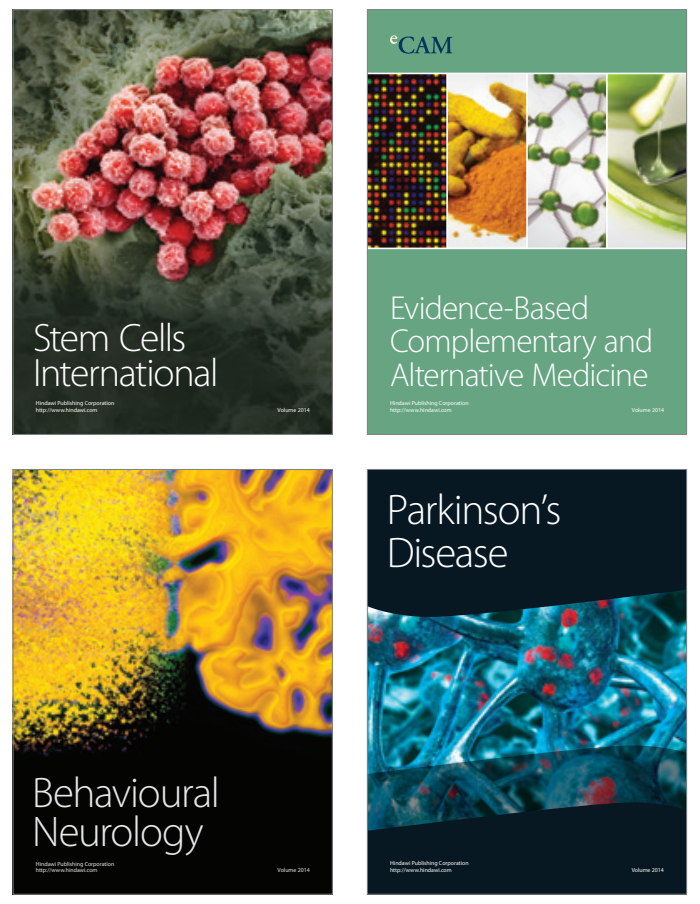
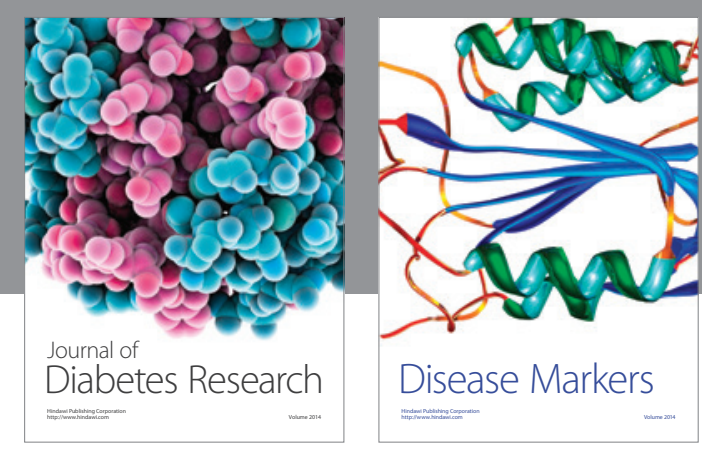

Disease Markers
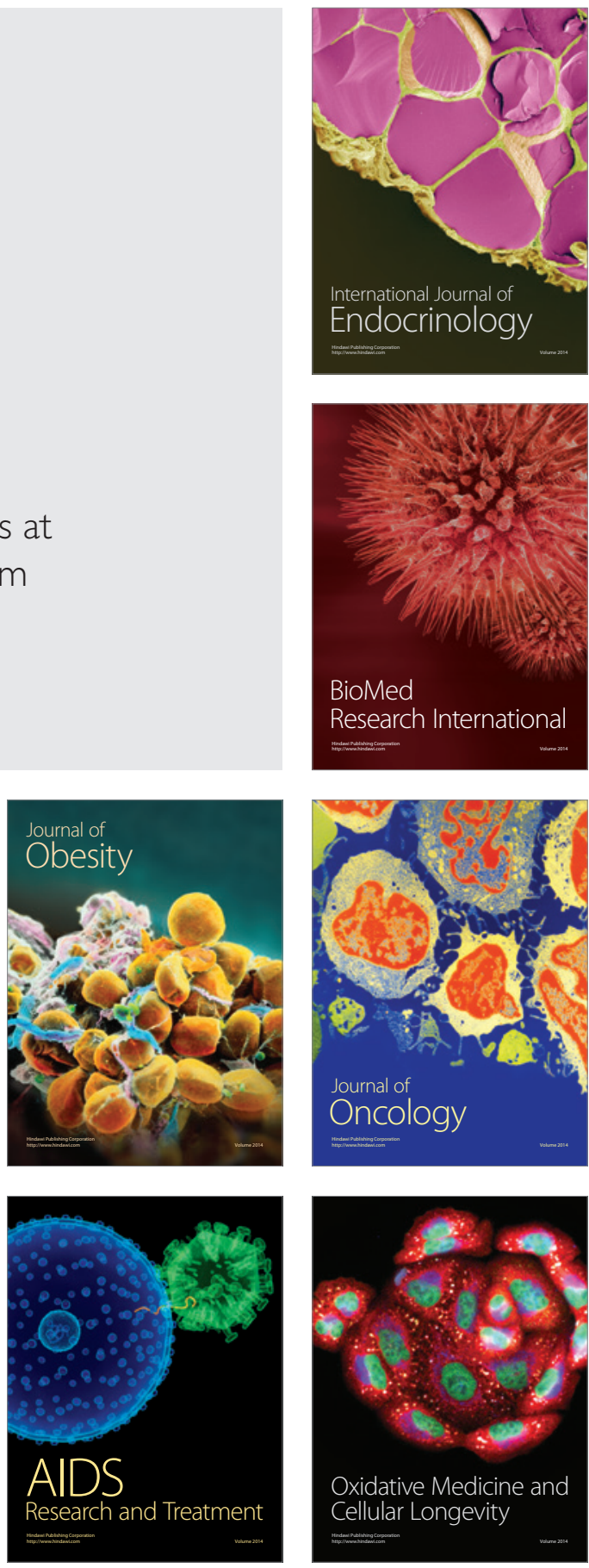